\title{
Rama, Canclini, Ribeiro: o intelectual na América Latina
}

\author{
Francisco Oiticica Filho*
}

Este trabalho pretende apresentar o pensamento de Angel Rama, Néstor Canclini e Darcy Ribeiro a respeito da formação cultural latino-americana e proceder a uma análise comparativa de cada uma destas contribuições, vistas sob um prisma político e literário, o que remontaria ao estabelecimento da figura do intelectual como homem de letras - escritor, teórico e ideólogo - desde quando, em 1892, o romancista Émile Zola, autor de importantes obras do naturalismo francês, como o germinal, intervém no célebre "Caso Dreyfus", fazendo com que, através dos jornais, viesse a público a figura do escritor no papel de intelectual defensor de idéias do interesse público.

Indivíduo que se responsabiliza em pensar a coletividade, propondo estratégias de política cultural, o intelectual moderno é, sobretudo, um criador de textos literários pelo qual se notabiliza, mas ao que acrescenta uma dimensão pensamental e cívica crítica.

Angel Rama, Néstor Canclini e Darcy Ribeiro são explicadores da "latinidade" para a qual desenvolveram, respectivamente, os conceitos de transculturação; hibridismo intercultural; e cultura de povos novos, povos transplantados e testemunho.

Para iniciar a discussào a respeito da formação cultural latino-americana é preciso saber o que se entende por cultura, e se persistem na cultura americana traços originários, propriamente autóctones, ou se podemos começar a partir da aceitaçào de sua natureza impura, isto é, misturada de nascença, não primitiva.

Respeitando a etimologia do termo, deve-se partir do conceito de cultura derivado do latim colo-cultum-colere: cultivar, habitar, e, por extensão, viver. No modo de cultivar, na forma de morar, e no jeito de viver é que iremos encontrar os primeiros vestígios das matrizes formadoras de cultura de uma gente.

Professor Assistente DECOS-CHLA-UFAL. Doutorando em Literatura Brasileira. Programa de Pós-Graduação em Letras LCV-CHLA-UFAL. 
Cultura não significa, apenas, ilustração e progresso, e sim, idéias, comportamentos e, sobretudo, fórmulas de açào sobre a natureza para o provimento da subsistência.

Cultura significa "um processo de social de produção" (Néstor Canclini), produto coletivo da vida humana que não pode ser entendido sem referência à realidade social de que faz parte.

Esta realidade fez prevalecer, nas Américas, as instituições, as línguas, os costumes, os mecanismos de ordenação sócio-econômicos do elemento civilizador sobre as populações de origem indígena, africana, e mestiça majoritárias. Mas, até quando? Se os frutos da civilização, contudo, não atingiram a massa da população, parece que, com Rama, Canclini e Darcy, as "categorias apagadas" que são estas populações majoritárias reagem.

$\mathrm{Na}$ Europa, KULTUR é termo de origem no romantismo alemão em oposição à ZIVILISIENHEIT que quer dizer civilização, usado para simbolizar o esforço germânico, em oposiçào à ostentaçào da corte francesa, sua antípoda. Enquanto na Inglaterra e na França civilização dizia respeito às normas de etiqueta $\mathrm{e}$ ao domínio da tecnologia, na Alemanha este termo estava ligado às realizações materiais da população. Cultura referia-se aos dons espirituais, à tradição, a singularidade e inventividade de um povo, enquanto civilização aos elementos de progresso científico e expansão territorial.

Desde os movimentos pela independência dos países sul-americanos vamos ver o enfrentamento destes preceitos, com sua confrontação à realidade local. $O$ mito de fusão das três raças formadoras - branco, negro, índio - da brasilidade, presente em Gilberto Freyre, Caio Prado Jr., e Sérgio Buarque de Holanda, foi a busca de uma primeira síntese, suscitando a idéia da existência de uma tradiçào mais remota que a do colonizador europeu, assim como uma incômoda diluiçào dos conflitos, que marcariam nossa colonização.

A partir da década de 30 o caráter nacional brasileiro - americano, passaria a se constituir em preocupação de cientistas sociais, demarcando períodos históricos de estudo, da Revolução Mercantil do Século XVI que sustentava as grandes navegações e determinara a expansão territorial da Europa, ao modernismo histórico e cultural, marco da nossa independência estética.

A "data-fetiche" de 1492 assinala um doloroso encontro que resultou na 
desestruturaçào de culturas estabelecidas já há mais de dez mil anos em território americano.'

Foi de antagonismo, mais ou menos declarado, que se deu o contato entre índios e brancos, americanos e europeus, ao longo destes quase quinhentos anos de história. O surgimento de uma ideologia exploratória planetária vem a acentuar estas tensòes, agora junto a populaçòes transferidas de seus núcleos comunitários para a periferia das grandes cidades. O tipo de desenvolvimento imposto ao chamado "Novo Mundo" tem reforçado aquela relação de dominação impossível de beneficiar a todos, e esgotado os recursos naturais do continente. Digno de mençào, a este respeito, é a designação "brasileiro" aos nativos da região, querendo identificá-los pela funçào de derrubadores de árvores pau-brasil.

Isto mostra que foi desperdiçado o saber das culturas nativas. Não havendo provas de que os habitantes do território americano, à época da chegada dos exploradores europeus, fossem autóctones ${ }^{2}$, ainda assim estes elementos elaboraram uma compreensào do espaço que nào ficava a dever àquela trazida pelo conquistador, portador de uma concepção imaginária da América dirigida para a satisfação de suas fantasias de riqueza, fartura e desmedimento, ${ }^{3}$ enquanto os indígenas atribuíamna forma, funçào, e sentido diferentes.

A diferença mais acentuada que marcou a apropriação territorial por parte do europeu foi o fato de que para ele este espaço era fonte de recurso, e não vetor

I"Até recentemente predominava a tendência conservadora que colocava, na pior das hipóteses, uma ocupação de 10.000 anos (...) Agora, porém, vêm-se multiplicando as datações radiocarbônicas, e, com elas, propostas de reconsiderações para a cronologia (...) É o que está ocorrendo com o nordeste brasileiro (...) Com plausibilidade foram produzidas datações de 48.000 , que podem ser projetadas até algo como 60.000 anos". Ulpiano Bezerra de Menezes in “A Construção Original do Território Americano". Revista USP, S. Paulo, 1992, p. 10)

2 "Inexiste qualquer fundamento para imaginar que o processo de hominização desenvolveuse também aqui (...) o continente americano permaneceu substancialmente isolado (...) até após a chegada das levas originais. O rompimento apenas se deu, ao final do século XV, com a chegada dos europeus". idem, idem, p. 19.

3 "Os livros "Visão do Paraíso", de Sérgio Buarque de Holanda, e "Invençào da América", de Edmundo Ógorman, nos mostram, com detalhes e precisão, a importância de todo o imaginário europeu na constituição da América (...) A descrição da América é feita na medida em que o imaginário (...) mantém intactas as visões do mundo tipicamente européias. Janice da Silva in "O Paraíso perdido: descrição e negação da terra descoberta." idem, p.19. 
de vida social, e que aquele tempo um momento vazio por onde se atualizariam os modelos europeus de civilização, não o tempo do mito de origem das nações indígenas.

A descoberta da América criou e difundiu uma linguagem que se esforçou por adaptar as realidades encontradas e a manutenção do universo europeu, desperdiçando ensinamentos dos povos aqui encontrados.

Com a expansão colonial européia, o conceito primitivo de cultura seria articulado ao universalismo da perspectiva ocupacionista traçada com base na teoria evolucionista das espécies. Como maneira de integrar um número cada vez maior de mão-de-obra escrava e/ou colonizada, e também conquistar novas fontes de riqueza e novos mercados consumidores, o conceito de cultura lança mão de estratagemas de conquista que atestaram, inversamente, a diversidade do gênero humano.

À medida que resistiam ao avanço ocidental, ganhava força, entre os nativos, a noção da especificidade cultural dos povos americanos, o que, se obrigou a revisào nos paradigmas etnocêntricos do conquistador, consumou a "devoraçào" simbólica das diferenças com sua absorção pela cultura massiva do consumo.

Poderia-se falar, nào em oposição, mas em complementaridade do par culturanatureza, desde que se considere a origem da cultura humana coincidentemente ao desenvolvimento biológico do Homos Sapiens. Assim, a visão naturalizadora de cultura, posse do nativo americano, coloca em outros termos os métodos de exploraçào civilizatória do meio ambiente, fazendo-nos pensar em uma retroinfluência americana sobre os modelos de desenvolvimento econômico e social implantados.

A preocupação das ciências humanas modernas, definidas a partir da abertura para o "outro", não-europeu, foi a de gerar modelos compreensivos das especificidades regionais dos processos de significação que só têm existência examinados em relaçào a uma série de elementos de cultura interdependentes. Os "estudos culturais", encarando as línguas como uma de suas unidades de trabalho, atestam nào ser possível reivindicar pureza nem originalidade para as experiências que resultam no patrimônio social.

As línguas constituem sistemas culturais de símbolos de comunicação de idéias e emoções que refletem as alterações experimentadas pela cultura. Assim como se pode falar de uma miscigenação racial pela mistura de caracteres geneticamente transmissíveis, também se falaria em uma mutação lingüística e cultural do tipo que se processaria em solo americano.

Outra unidade do complexo constituído por uma populaçào a servir de estudo é a etnia, que pode ser até relativamente heterogênea, mas se distingue das 
demais etnias pela unidade lingüística e cultural, e a auto-consciência desta singularidade. Entre sociedades complexas como a latino-americana, a natureza simbólica da cultura vê-se acrescida de elementos complicadores de classificação, descriçào, e análise. Porquanto o comportamento humano tenha não só aspectos técnicos e pragmáticos, mas, principalmente, simbólicos e expressivos, em uma sociedade complexa a identidade de um grupo nào é mais determinada segundo uma única visào de mundo, mas se faz de verdadeiros antagonismos.

No estudo de sociedades complexas ${ }^{4}$ o problema se desdobra, pois a representaçào do comportamento individual vem disfarçada e carregada de ambigüidades. Considerando-se a ambigüidade existente entre os diversos níveis de produção simbólica, reforça-se a compreensão de que cultura não é uma entidade estática. Os próprios indivíduos, em suas biografias, interferem na cultura e escapam ao controle das forças impessoais.

Todo determinado sistema sócio cultural gerador de individualidades funciona como detonador de valores que se fazem destas biografias, quando os símbolos sào manipulados e transformados em novas situações. Há uma correlação entre a velocidade de transformaçào da sociedade urbana-industrial contemporânea e a super-produçào de novos símbolos e alteraçòes na cultura.

Para se falar de cultura nacional, e continental, há que se pressupor algum tipo de predominância na coexistência de códigos entre as culturas e sub-culturas existentes. A identidade de um grupo seria um caso de controle sobre os significados dos símbolos enquanto códigos de comunicação, uma vez que estes códigos têm, necessariamente, de ser, parcialmente, indecifráveis.

O caráter nacional considera, daí, a produçào cultural como fator de diferenciaçào, através da qual ele se afirma e difere. Cultura é o patrimônio social constituído pelo conjunto e integraçào dos modos de fazer, de interagir, e de simbolização desenvolvidos ou adotados por uma sociedade, como soluçào para as necessidades da vida humana associativa. ${ }^{5}$

"Ver "O conceito de cultura e o estudo de sociedades complexas" sobre a posição do antropólogo - e todo cientista social que faz parte da comunidade que estuda - diante de uma sociedade urbana, de Gilberto Velho e Eduardo Viveiros de Castro in apostila do Museu Nacional da UFRJ, s/d.

'A orientação deste estudo segue os passos de Berta G. Ribeiro, antropóloga que, fomentando os estudos sobre os elementos materiais da cultura indígena, desde a década de 50 , criou condições para o trabalho da história da cultura efetuados posteriormente pelo seu companheiro de então, Darcy Ribeiro. 
Neste século, incrementaram-se estudos de tensões em relação às experiências dos povos saídos do colonialismo, que, em situações de mutação se revoltam, na medida em que os valores básicos são reformulados. Foram exatamente os movimentos nativistas latino-americanos os mais estudados quanto ao tipo de reação no momento de uma situaçào de mobilidade institucional sociocultural.

A cultura latino-americana é campo fértil para descoberta dos ritmos de transformação, concebida em região permanentemente assolada por instabilidade as quais incorpora em "diarréia" para depois recorrer a princípios de correção ou reforço de uma inércia institucional regressiva. Desde os "descobrimentos", na passagem do século XV para o XVI, o tradicional sistema de simbolização da vida oscilava entre visão de uma Idade de Ouro idealizado no passado, até o de um paraíso prometido para o futuro, entre o medo da novidade e uma escatologia redentora.

A ideologia cristà da catequese, com o expediente das "reduçòes" e dos "aldeamentos", cultivou uma simulação de instituição que abastecia de imagens um discurso civilizatório, pela mistura da cultura material indígena com os modelos de imaginária européia. Dentre os indígenas nos aldeamentos, era escolhido um "chefe", "(...) que não tinha outra autoridade que senão a servir de "língua", de "transmissor", de ordens de administradores" (Mendes Jr., 1912, p. 31).

Muitas das discussòes travadas para dar conta do "trauma" da colonização tentam explicar o relativo fracasso da América Latina frente aos seus vizinhos do Norte. A tese da superioridade norte-americana levou a que se propusesse a "desindianização" desta parte do território, como maneira de se livrar da tradição obscurantista que juntou a melancolia de Portugal e Espanha, “(...) agravada pela miscigenação desenfreada com a indolência do sangue índio e o misticismo do africano” (Moreira, 1998, p. 7).

Atualmente, a mescla racial tem recebido melhor tratamento por parte dos que a consideram requisito para a entrada no século XXI, que será o da mistura por excelência, a ponto de vinculá-la ao projeto da pós-modernidade. ${ }^{7}$

\footnotetext{
"Brasil - Diarréia", Teoria de Hélio Oiticica, artista plástico brasileiro, que propunha transformação radical dos conceitos-valores vigentes de "convi-conivência" (hábitos da sociedade brasileira: cinismo; hipocrisia; ignorância) visando criação de linguagem que fizesse o conceitual submeterse ao fenômeno vivo. "Tudo o mais é diluição na diarréia" in "Aspiro ao grande labirinto", Rocco, Rio de Janeiro, 1986.

"Ver "O desafio da mestiçagem", entrevista de Jacques Le Goff, historiador francês, em que conclama os intelectuais a preparar os povos para mistura racial. 28 de setembro de 1997, caderno MAIS, Jornal Folha de São Paulo, p. 5. Outros filósofos-pensadores fazem da mestiçagem corpus de seu trabalho, como Michel Serres em "A filosofia mestiça".
} 
Decorrente do entusiasmo capitalista com o fracasso do modelo socialista estatal e centralizador, aposta-se no esgarçamento de fronteiras nacionais e no esmagamento das diferenças culturais. Mas não é o que necessariamente acontece. A globalização configurou uma crescente interdependência mundial que estimulou, também, um movimento em direção ao regional, fazendo coexistir uma certa homogeneidade de ofertas de bens simbólicos criando uma classe média universal tendendo para um mesmo padrào de consumo, comportamento e aspiraçòes, ao mesmo tempo com o recrudescimento dos movimentos reivindicatórios de direitos identitários ligados à participação nos benefícios do progresso industrial.

A América Latina passa a pensar em bloco, para fazer frente aos processos de fusào empresarial transnacionais, que criam conglomerados econômicos, mas também, para reagir às pressões dos blocos comerciais que, no norte, ligam EUA, México e Canadá - integrantes do NAFTA - e, na Europa, o Mercado Comum Europeu, com sua perspectiva de incremento cultural internacional.

O Pacto Andino, a ALCA, e o MercoSul surgem, assim, como iniciativas próprias para dar consecuçào ao projeto mundial de incremento da massa crítica visando obter poder de barganha maior nas negociações no mercado mundial de bens econômicos e culturais.

Agora expostos à tecnologia, e alimentados pelas mesmas fontes midiáticas de informaçào, o Brasil e a América Latina, vêm-se provocados à acompanhar o fluxo de transformação geral, sofrendo alterações significativas no modo de gerência da dinâmica cultural interna. A construçào da imagem de "latinidade" passaria, entào, pela açào midiática, atravessando a sociedade massiva e sorrateiramente, sem que nos déssemos conta, e de tal forma que ela só acontece através dela.

Os meios eletrônicos de difusão de informação e mediaçào comunicacional interfeririam na produçào intelectual formatando o real, via de acesso que permite “(..) ver-se tudo sem nunca se ser visto" (Marcos. 1994. p. 67). Promove a interiorização dos mecanismos de controle e eficácia, sem a exteriorizaçào da dominaçào, como se tudo se passasse "naturalmente", de forma invisível, disciplinar e autônoma, o que desloca o combate intelectual do campo de ação ideológica.

Este poder midiático produz parte da realidade através de rituais de verdade não mais históricos, mas tecno-científicos; nào mais reproduzindo ou comentando, mas construindo e simulando o real, decidindo quais aspectos de atualidade merecem ser produzidos e entregues ao público. Os fragmentos do real adquirem força de totalidade através dos discursos midiáticos, constituindo o "paradoxo do espaço público vazio" que permite "(...) vermos mais sem, no entanto, vermos melhor o conjunto". (idem, p. 71) 
O intelectual latino-americano se defronta com esta outra linguagem desmaterializada e desreferencializada - alterando a medida da intervenção literáría nos processos de significação, fora dos padrões tradicionais baseados na polaridade nativo/estrangeiro; real/imaginário; centro/periferia.

\section{Angel Rama: transculturaçāo}

Crítico literário e professor de literatura latino-americana da Universidade de Maryland, EUA, o uruguaio Angel Rama, falecido em 1983, busca formular, em seus estudos, a sintese que resolva o trauma da colonização que levou, em nosso continente, ao abafamento de muitas tradições ameríndias.

Diferentemente de outros pensadores de extração sociológica, o assunto de que trata como objeto de demonstração - a literatura regionalista de língua espanhola - considera um patrimônio lingüístico mais específico.

Em Transculturação na narrativa latino-americana (1975) propòe reverter a dominação centro-periferia que deixaria a cultura latino-americana a reboque da européia, para creditar ao regionalismo indigenista, e ao ruralismo, a capacidade de salvaguardar os valores da tradição - uma "outra" tradução, mais remota e nào contaminada pelos valores da civilizaçào - que renovaram a literatura do Cone Sul.

O influxo modernista das cidades apontava para a destruição dos movimentos narrativos, confrontando os realismos fantásticos e social e a narrativa regionalista. Ao invés de se submeter à pressão universalista modernizadora, a narrativa latinoamericana, seguiu outra orientação: a transmutação do regionalismo, com o coloquialismo da linguagem provincial passando para o primeiro plano do texto, recebendo, agora, o tratamento artístico e experimental das vanguardas européias.

Angel Rama destaca o valor positivo do elemento da tradição para impedir a ruptura com os setores que compòem a cultura latino-americana. O patrimônio lingüístico mantido pelo regionalismo foi responsável pela integração da novidade na traduçào, alternativa para a "rigidez-cultural" fossilizante e para a "vulnerabilidade cultural" que aceita passivamente as proposições externas.

A "transculturaçào" seria processo transitivo que evita a aquisição de uma cultura por outra e garante a renovação de uma tradição. Retém valores peculiares positivos de uma estrutura cultural capaz de se renovar sempre, sujeita ao processo de perda (desculturação) que incorpora a novidade, e de dominaçào cultural (neoculturaçào) quando se dá a absorçào de uma pela outra.

Em "A cidade das letras" (1984) Rama afirma que se deu a conquista do território americano com a fundaçào de cidades, o primeiro plano de urbanizaçào do 
continente, "reiterando a concepção grega que apresenta a "polis" civilizada à barbárie dos não urbanizados" (p. 35). As palavras e os diagramas gráficos projetaram a ocupação antes mesmo da construção desta civilização. A posse da terra americana era antes emitida pela palavra escrita - a escritura vivendo como a única válida - em oposiçào a palavra falada e que pertencia ao reino do precário.

Sobre este primeiro discurso ordenado, proporcionado pela escritura, se articulava-o proporcionado pelo desenho gráfico. $O$ plano foi sempre o melhor exemplo de modelo cultural operativo, autorizando todo tipo de operaçòes intelectuais superpondo tradições.

O "uso da letra" instrumento de colonização, como alavanca de ascensão social-verticalizada - e integraçào na sociedade internacionalista e burguesa que o desenvolvimento gerava, foi também fator de modernização pelo qual se exerciam as profissòes "liberais", menos diretamente ligadas ao poder, que buscará absorver as reivindicaçòes dos setores mais baixos.

A "cidade letrada" se institucionalizava para manter viva a coesão em torno de um certo código lingüístico - apenas a transposição da língua espanhola (Academia de Letras hispano-americana), ou como a afirmaçào de uma língua nova (Academia de Letras brasileiras e argentinas) (p. 86). A formaçào de uma elite intelectual, a emergência de um público leitor, os novos partidos, fazem parte desta "cidade das letras" onde convivem setores independentes com os mais ligados ao poder a partir dos modelos europeus. No Brasil, o domínio da palavra escrita que exigiria poder de concentraçào e esforço de abstraçào generalizante capaz de formular projetos para o país, foi sempre negligenciado em favor do uso retórico da linguagem, em que a exibiçào de efeitos sobrepunha-se à necessidade da comprovação das idéias expostas, do que é exemplo o "bacharelismo" novecentista (ver "Algumas características do sistema intelectual brasileiro" in Lima, 1981, p. 15).

Angel Rama destaca o valor positivo do elemento da tradiçào para impedir a ruptura dos setores que compòem a cultura latino americana, uma vez que nossa não era aquela tradição, culta e burguesa; combatida pela vanguarda européia, e sim a tradiçào popular.

Para Rama, a questào da renovaçào estética, que entra pelos centros urbanos defensores da modernizaçào, será resolvida quando do encontro com os traços peculiares das culturas rurais, não sem "perdas forçadas" para ambos os lados.

O patrimônio lingüístico latino americano mantido pelo regionalismo e as culturas nacionais foram responsáveis pela via da integraçào da novidade na tradiçào, alternativa para a "rigidez cultural" fossilizante e, para a "vulnerabilidade cultural" que aceita passivamente as proposiçòes externas. 
A lição do avanço vanguardista sobre a periferia foi a da valorizaçào do nosso patrimônio artístico-cultural, o "outro" pimitivista do europeu que, para nós tornou-se o "mesmo", isto é, nosso passado colonial, nosso caldeirão interétnico multirracial "a preciosa contribuiçào de todos os erros" dai resultante.

Efeito maior, da transculturaçào, é o de ir rechaçando o colonialismo interno, na medida em que seja possível aproveitar do confronto entre metrópole e província influências que colaborem para soluções singulares.

A miscigenação, a mestiçagem, o canibalismo amoroso, a antropofagia, no âmbito da pesquisa de linguagem, seriam elementos de uma tradição transcultural latino americana, pois que se afirmam sem pagar tributo à qualquer ideologia hegemônica, constituindo novas sínteses criativas capazes de retro-alimentar, até, as bases modernistas internacionalizantes.

Da tensão entre resistir e liberar, entre manter-se isolado ou perder as tradições, resulta uma força que vai transitar entre o mundo agrário e o industrial, o camponês, o índio e a burguesia.

Paralelo que poderia ser feito com a Antropofagia osvaldiana, variando o status desfrutado pelo regionalismo, sabidamente resistente às idiossincrasias paulistanas. No Brasil, regionalismo distinguia a produção artística de norte a sul do país, opondo futuristas e tradicionalistas, ao que identificavam de tendências destrutivas naqueles.

O cenário sobre o qual se debruçou Rama era outro. Para os escritores não brasileiros estava disponível um outro repertório lingüístico em que as línguas indígenas produziam seus próprios dialetos e variaçòes. Foi se aproveitando deste patrimônio que a transculturaçào inventou formas sintáticas e significados novos.

Assumir o artificialismo da língua literária e manter o uso corrente da linguagem, substituir a língua do escritor - língua culta - pelo dialeto regional, dar um tratamento artístico às variaçòes de linguagem locais foram elementos de unificaçào literária do texto artístico.

O escritor mergulharia na língua dialetal não para mimetizá-la, mas para criar dentro dela, fazendo-se passar pelo seu "outro", o indígena, o primitivo, o nativo, equação que vai levá-lo de volta a um tempo de outra tradição, antes dela ter se formado, de onde retorna hibridado: um "tupi tangendo um alaúde".

Reúne ao seu talento de escritor uma identidade flutuante, falando de dentro de uma comunidade lingüística que nào é a sua, mas que trata como tal, tendo, no entanto, um outro domínio do discurso literário.

Interessante estratagema da modernidade latino americana, em que escritores, em um processo de anamnese, fingiam lembrar de algo que nào viveram para daí retirar parte do conteúdo de seu trabalho. 
Para Guimaràes Rosa, principal autor, segundo Rama, brasileiro, a se utilizar do procedimento transcultural, fundamental foi a aproximaçào das fontes clássicas ao mesmo tempo que do nosso narrar espontâneo, da oralidade dispersiva, da tradição analfabeta. Esta aproximaçào foi nào idealizada, no seu sentido casuístico, nem ingênua, no sentido do despreparo para seu enfrentamento, mas intencional e conscientemente explorada.

A narrativa latino americana pôs, no plano semântico, em suspenso, a linearidade discursiva e a crença no valor de objetividade da racionalidade, introduzindo a lógica realista no mundo das imagens oníricas, das "comoçòes anímicas", primitivistas.

Alguns dos produtos da transculturação foram, porém, resposta acessível aos desejos de acomodaçào da retórica vanguardista à realidade regional latinoamericana. Nào será demais sublinhar a dose de convencionalismo que adquiriu a combinaçào de mitos, materiais fronteiriços aos regionalismos, em muitos dos sectários da transculturaçào.

Pensar e sentir como nativo, e se exprimir em língua literária, fazendo dialogar o indigena e o europeu, mediado pelo escritor que domina ambos os universos imaginários, sintetiza o esforço de transculturaçào da narrativa latino-americana.

\section{Néstor Canclini: hibridação intercultural}

O argentino Néstor Garcia Canclini tem sido o mais festejado entre os cientistas culturais latino-americanos cuja maturidade produtiva foi atingida já no decorrer dos anos 90. Canclini causa escândalo quando diz que consumir nào é pecado e que, na cultura contemporânea, através do consumo as pessoas se autodefinem descobrindo a si próprias e transformando-se em cidadàos. Esta é a tese de seu livro "Consumidores e cidadãos - conflitos multiculturas da globalizajăou" (1995).

Canclini encara a cultura como lugar estratégico e arena privilegiada na definiçào política de modelos sociais e econômicos, em oposiçào às correntes "materialistas" do pensamento crítico continental.

Ele redefine cultura como sistema globalizado de telecomunicaçào em convergência ao conceito de "midiasfera" de Régis Debray e do pós-modernos americanos. Tanto a cultura crudita quanto a cultura popular tradicional tornaram-se secundárias em relaçào à cultura de massas "mediatizada".

Canclini propòe uma nova pedagogia com base no elogio aos hibridismos. Duas abordagens da questào cultural sofreriam entào o teste de confrontaçào com esta hipótese. Canclini mostra que formas culturais híbridas, cruzadas com elementos da cultura do consumo americanizado, acabam por neutralizar a homogeneizaçào descaracterizadora melhor que os idealismos da preservaçào de raízes. 
De um lado ficariam os que identificam na mídia um mero instrumento de dominaçào do imperialismo norte americano. De outro os que pregam uma modernização a todo custo dos recursos culturais dos países do continente.

Em todas as formas culturais da contemporaneidade pós-moderna latinoamericana - a música, a moda, a literatura - a identidade é continuamente negociada num diálogo tenso e produtivo com as mensagens que o sistema global faz circular. Tal renegociaçào permanente define o conceito atual de hibridação intercultural.

Em outra obra, mais recente, "Culturas hibridas, estratégias para entrar e sair da modernidade" (1997), Canclini aproveita sua permanência no México para analisar as formas de interaçào simbólica e material entre as culturas americanas e mexicanas que criaram a figura híbrida do "chicano".

Os processos de hibridação tais quais os de "descolecionamento" (p. 302 a 309) - inversão de tendência ao trancafiamento, posse, e distinção conferidos aos bens simbólicos - o de "desterritorialização" (p. 309 a 326) - percursos de perda do referente identitário e a sua recriação em territórios novos - e o de "gêneros impuros" (p. 336 a 345) - nascimento de formas de manifestaçào artísticas que são situaçòes de intercessão entre linguagens, categorias e disciplinas, surgem ao examinar as culturas híbridas geradas ou promovidas pelas novas tecnologias comunicacionais, pela reorganização do público e do privado no espaço urbano e pela transitoriedade dos processos simbólicos.

Argentino com grande vivência das condições em que se dão os contatos e as formas de adaptação, alteração e mudança de padrões culturais, a que foi estudar em áreas fronteiriças do México com os Estados Unidos, Néstor Garcia Canclini desenvolveu o conceito de hibridaçào inter cultural dos conflitos interétnicos, vendo aí, Canclini, como se desmoronaram as categorias que tentam simplificar as estratégias de afirmaçào cultural entre grupos populacionais, sejam eles mais identificados com tradições de classe, de etnia, ou de nacionalidade.

Formado pela noçào antropológica de cultura, ele mesmo, trabalhando na Escola Nacional de Antropologia e História do México, sugere compreendermos o significado de hibridação como o cruzamento de culturas para aceitarmos a complexidade crescente das relações humanas na contemporaneidade.

Insatisfeito com as oposições entre nacional/popular, erudito/folclórico, subalterno/hegemônico, tradicional/moderno, passa a verificar uma convivência no mesmo solo de práticas sociais desses movimentos antagônicos, como rupturas e justaposições que deveriam culminar em outro tipo de organização de dados.

Avançando sobre a fronteira em marcha de volta a um caminho migratório já feito, reocupando um espaço territorial que lhe fora tomado, aumentando o 
contingente populacional mestiço nos Estados Unidos, os mexicanos da fronteira com uma tradiçào indígena ainda bastante pronunciada, vêm pondo em prática estratégias de ampliaçào do capital simbólico para além das fronteiras nacionais, neste processo a que Canclini chama de hibridaçào intercultural.

O êxodo rural e o aumento da populaçào urbana, fenômeno multidirecional, conta com uma oferta simbólica heterogênea que dispõe de uma rede transacional de comunicação a desfazer os limites divisórios entre comunidades isolados de centros urbanos desenvolvidos, e a oposiçào entre as categorias antes mantidas para preservar uma relaçào de subordinaçào do rural para o urbano, agora interconectados.

Ocorre uma fragmentação dos movimentos sociais que nào vão buscar sua legitimaçào pela ocupação dos espaços públicos, mas pela sua exposição à mídia eletrônica. O acompanhamento destes eventos midiáticos colocaria, portanto, as cidades e o meio rural em condiçòes equiparáveis de modernização.

No objetivo de nào mais recair na estigmatização do meio urbano, quando se atribuía uma perspectiva saudosista de uma harmonia campônia, e, às cidades, o ônus da desinvidualizaçào, e de perda do sentido comunitário da existência, Canclini avalia que esta reformulação do espaço público corresponde à reclamação do âmbito privado, e à uma reorganização das ações que visam impregnar de significação estes espaços.

"A hibridez tem um longo trajeto nas culturas latino-americanas" (1997, p. 326) afirma Canclini: Isto que se deu inicialmente como prática expoliativa, foi mais tarde potencializada como a chave para a descoberta e afirmação de nossas especificidades plurais e nào excludentes, o que nos colocaria em condição de arautos da pós-modernidade, "(...) pátria do pastiche e do "bricolage" onde se encontram muitas épocas e estéticas" (idem p. 24); a convivência dos contrários, a tarefa de "inventar" uma tradiçào de início problemático e difuso.

Canclini dedica seu esforço de compreensào para estudar as transformaçòes ocorridas desde os anos 80 na América Latina que mal recebem o resultado das propostas de "(...) modernizaçào como um processo sócio econômico que vai contrariando a modernidade" (idem p. 23). e já considera a mudança do que se entendia por tal, adentrando na pós-modernidade revendo os vínculos que o mundo moderno armou com as tradições que quis excluir ou superar.

Nas cidades latino-americanas, contrariamente o que afirmara uma história linear, as tecnologias comunicativas não substituem os usos tradicionais do passado e a simbologia dos espaços históricos.

Há um entrecruzamento de muitas forças na contemporaneidade latinoamericana que modifica os vínculos entre o público e o privado. Muito do que 
estava circunscrito à esfera de influência da cidade e que hierarquiza as relações e punha em oposição a "sociedade urbana" do "mundo rural", hoje sào reestrututuradas pela comunicação imaterial, criando interrelaçòes com base na recepção das mídias eletrônicas.

Então, se o uso massivo da cidade para encenação política se reduz, sendo substituído, muitas vezes, por "explosões desarticuladas, assaltos a lojas e supermercados (...)” (p. 287), subordinação das demandas sociais pela mediatizaçào às interaçòes realizadas em circuitos não materiais - a televisão, em particular - a eficácia dos movimentos de mobilizaçào social depende ainda da apropriaçào dos sentidos urbanos - monumentos, praças, ruas movimentadas - através de açòes que interfiram no funcionamento habitual da cidade e encontrem eco nos meios eletrônicos de informaçào.

A hibridização intercultural é feita também no contato entre o homem e os bens culturais do meio urbano, e entre estes e a mediação tecnológica. Apropriando-se dos mecanismos tradicionais de legitimaçào aos quais subverte, para melhor recepcionar as lutas semânticas que alteram o significado das mensagens dos outros, e ao elaborar um discurso conscientemente formatado para poder ser transmitido em rede, estes movimentos dào provas da necessidade de se reescrever politicamente a história cultural de uma nação.

O entrocruzamento da moda com as mensagens publicitárias, os dispositivos de reproduçào cultural ou populares, - fotos, clipes, games - o ecletismo arquitetônico e o desordenamento urbanístico fazem a "gramática de leitura da cidade" (p. 303) perder sua eficácia legitimadora, e solicitar uma abordagem desreferencializada, perante uma configuraçào instável hibridada, onde desaparece a noçào clássica de "sentido" da mensagem.

A decomposição da ordem clássica da modernidade permite a oportunidade de relativizaçào das concepçòes macro-estruturais que promoviam a desigualdade. Se, no entanto, esta "desordem" implica mudanças culturais, e estas mudanças dependem do uso que se dá aos novos recursos tecnológicos, ainda assim, as estratégias de apropriaçào e adequação destes recursos - que são desiguais - deverào ser intensificados de modo a promover uma democratização de criatividade e de experimentaçào.

A apropriação múltipla de patrimônios culturais já é parte de um processo de desvinculamento das classes sociais com os estratos culturais. A categoria de classe social nào reflete mais os cenários culturais e os cruzamentos multiidentitários dos agentes culturais no ambiente de produçào simbólica. 
"O espaço no modo contemporâneo" (Ortiz, 1996, p.18)" é desterritorializado, conceito que assume em Canclini um valor diferente. Para Néstor a idéia de proximidade e distância mudando como está e exprimem o caráter de uma modernidade que se radicalizou. O desenraizamento das culturas de um território físico possibilita uma mobilidade social mundializada, em que as oposiçòes entre cultura erudita e popular perdem o sentido, criando outros espaços de socialidade.

Para as localidades antes isoladas da América Latina isto significa a possibilidade de compartilhar de um imaginário coletivo em um movimento de mào dupla, de modo que, ao lado das marcas de produtos estrangeiros.que chegam trazendo suas referências culturais, haja uma absorção diferenciada de seus elementos gerando uma nova identidade que vai levar em conta a realidade local.

Enquanto existe um processo de perda de relaçào "natural" de cultura com territórios geográficos, ocorrem fenômenos de "reterritorializaçào relativas" (Canclini, 1997, p. 309) com a transnacionalizaçào dos produtos simbólicos, que faz, por exemplo, o "artesanato" receber o tratamento de "marca importada" em lojas de departamento multinacionais, e as migraçòes multidirecionais.

Ocorre a internacionalizaçào latino americana com a migraçào de todos os estratos da populaçào. Atualmente, segundo Canclini, a reflexào mais inovadora sobre desterritorializaçào está acontecendo na regiào fronteiriça entre México e Estados Unidos. Seja pela atualizaçào do meio informático de comunicaçào, seja pela
transnacionalizaçào da economia com a alocação de funcionários das empresas em diversos países diferentes, seja pela criaçào de um imaginário coletivo mundializado, ou a indeterminaçào crescente a respeito do enfoque racial das misturas étnicas nascidas do cruzamento entre genes já misturados, que nos EUA dificultam o controle demográfico, os particularismos nào perderam a força, apenas nào reivindicam uma "volta às raizes" nem vivem "crise de identidade", considerando a impureza da mistura elemento de cultura que enriquece a mescla racial.

Darcy Ribeiro: tipologia dos povos latino-americanos

O antropólogo brasileiro Darcy Ribeiro, fundador da Universidade de Brasília, auxiliar direto do ex-presidente Joào Goulart, até 64, e falecido ano passado quando

${ }_{8}^{8}$ Título de artigo de Renato Ortiz que substitui, para falar das transformações culturais, o termo "globalização", circunscrito à esfera econômica, pelo de "mundialização", concernente à radicalização e criação de uma "modernidade-mundo". in 1996, Revista Veredas, CCBB - Rio de Janeiro, p. 18 e 19. 
exercia o mandato de senador da República pelo Estado do Rio de Janeiro, começou seus estudos brasileiros quando do internamento nas matas amazônicas - junto à companheira antropóloga Berta Ribeiro - por períodos alternados que completariam dez anos de pesquisa da cultura indígena Kaapor.

Nestes contatos, que têm sua raiz nos programas de desbravamento dos sertões pelas expedições do Marechal Rondon, Darcy despertou para o relacionamento diferenciado dos primitivos brasileiros com seu meio baseado em sofisticada representação da natureza que incorpora ao mito, atribuindo poder de comunicação anímica às coisas do mundo.

Esta codificação naturalista da cultura, que modifica e integra o homem e a natureza em uma solidária rede de sinais, transpòe a dicotomia animal/cultural, vinculando o progresso da humanidade ao ritmo de transformaçào ecológica. Todo o patrimônio do saber indígena brasileiro é conservado pela tradiçào oral e material, ao qual dedicam especial esmero de realização, e pelo que relata a história da tribo.

A adaptação à floresta é essencial e condiciona a cultura. Toda a linguagem é derivada da experiência de contato com a mata. Assim, KAA é mata, e POR é morador, o que quer dizer, que, para aquela gente de Darcy, ser da natureza é sentirse alguém, e por ela ser identificada.

$\mathrm{O}$ aprendizado de Darcy marcou determinantemente sua reflexào sobre o processo civilizatório brasileiro, no qual detectava elementos de exploração predatória, principalmente no uso dos recursos naturais e humanos.

Ao saber minucioso dos Kaapor, acumulado em milênios de convívio com a mata, capaz de fazê-los saber a espécie e serventia de cada árvore, denominar cada bicho ou inseto, possuir dezenas de designações para o verde da floresta, Darcy antepõe o "assalto” que a Amazônia sofreu por “(...) tecnocratas que só se preocupam com projetos que cheiram a lucro e a propina” (Ribeiro, 1992, p. 68).

De conotaçào utópica, o "brasilianismo" de Darcy, ao apoiar-se na experiência adaptativa bem sucedida dos indivíduos e recusar os padròes civilizatórios da modernidade, buscou o efeito estético, inaugurando outro referencial abertamente endógeno, orgulhoso de sua condição nativa.

Assim é que afirma:

Através de um esforgo milenar, as populaçoes indigenas baviam conseguido implantar-se dentro desse ecosistema, tirando dele sua sobrevivencia. Sem ameaçar a reprodução da floresta; a civilização surgiu ali como uma peste de agressão ecológica avassaladora que simultaneamente extermina quase toda a população indigena e líquida a própria floresta, com intensidade cada veq maior. Em nossos dias, a eficácia da destruição civilizatória é já 
tão grande, que não se pode mais duvidar de que a floresta amąôninica está ameaģada de morte (Ribeiro, idem. p. 73)

Quando de sua passagem pelo governo do Estado do Rio de Janeiro como vice-governador, Darcy elaborou a doutrina do que seria um "socialismo moreno", opção pela etnicidade como programa político que expressa a sua formação de antropólogo.

Darcy Ribeiro, define cultura a partir do exame das populaçòes primitivas para promovê-las a fator de desenvolvimento nacional, em um projeto utópico de "redescoberta" das Américas.

Para ele pode-se falar em uma retro influência americanista indígena sobre as sociedades européias, influência esta nào reconhecida com óbvia estratégia de ocultamento dos interesses mercantis. O manejo dos recursos naturais e uma ecologia enraizada na cultura, como forma de relacionamento com o meio que impregna o discurso mitológico, se apresentam como alternativa para o avanço das técnicas industriais de exploraçào implementados pelo conquistador europeu fadados a levar ao esgotamento e dos recursos naturais.

Darcy Ribeiro realça a matriz indígena na formaçào do Brasil-nação a partir da noção primitiva de cultura derivada do latim colo - cultum - colere: cultivar, habitar, viver.

A partir da década de 30 o caráter nacional brasileiro se constitui em objeto de preocupaçào de cientistas sociais. Da tríade Caio Prado Jr., Sérgio Buarque de Holanda, e Gilberto Freyre se distingue Darcy Ribeiro pela eleição dos povos detentores da cultura mais singela - a civilização da palha dos povos nômades brasileiros - para construçào do sentido de brasilidade.

Nas subculturas regionais identifica as técnicas adaptativas indígenas. A cultura rústica brasileira seria subsidiária dos modos de produçào doméstica - no pequeno sitiante - indígena; as crenças e crendices relacionadas à conservação da natureza e ao convívio social, transmitidos oralmente, vào beber nas fontes primitivas.

Este traço de oralidade constituinte da tradiçào popular distingue o processo civilizatório brasileiro no interior de um continente latino americano em que os demais países conheceram uma literatura indinista escrita.

Para Darcy, importante foi a miscigenaçào genética e cultural entre o indígena da costa e o colonizador luso-europeu plasmada nas primeiras décadas após a descoberta criando uma unidade cultural do Amazonas ao Rio Grande do Sul, prota-célula para a qual pouco contribuiu o elemento negro, aproveitado muito mais como "carvào-humano", mào de obra escrava "queimada viva" no eito. 
O veículo desta cultura foi o nheengetu ("língua boa") fundado esistematizado pelo jesuíta, fruto da mistura de dialetos tupis com a ortodoxia católica, religiào dos dominadores, impregnada de tradições e crenças indígenas.

Darcy Ribeiro classificou as configuraçòes histórico-culturais dos povos extra - europeus modernos em três categorias diferentes: Povos Transplantados formados pela expansão de nações européias que retomaram suas formas originais de vida sem se misturar com a população local; Povos Testemunhos constituídos de remanescentes atuais de altas civilizações originais contra as quais se choca a expansào européia sem conseguir, contudo, assimilá-las; e povos Novos, que concerne às populaçòes oriundas da mestiçagem e do entrecruzamento cultural de brancos com negros e com índios de nível tribal sob a dominação dos primeiros, que de um passado sem glórias nem grandezas sào uma espécie de "tábua rasa" para o colonizador.

Em O processo civilatório, As Américas e a civilização e Os brasileiros, elaboram uma tipologia para a colonizaçào americana. Resultado da revoluçào mercantil e da expansào da Europa em 1500, foram gerados três tipos de populaçào com traços culturais distintos a balizar o estudo do processo civilizatório latino-americano. Os "Povos testemunho" do México, Guatemala, Peru, Bolívia e Equador que resistiram à chegada do europeu lançando mào de suas tradiçōes ancestrais às quais faziam frente ao estágio de desenvolvimento dos países de origem do invasor, e que ficaram, ainda que despauperados, como a memória e instrumento de açào das geraçòes posteriores. Os "Povos transplantados" Uruguai e Argentina, reproduziriam em solo americano o modelo de civilizaçào européia com a erradicaçào das marcas locais e uma adaptaçào forçada ao cenário americano dos padròes de produçào e consumo culturais. Os "Povos novos" do Brasil, Venezuela, Colômbia, Chile e Antilhas, criam-se sobre um território que parece desocupado ao invasor, pelo fato que encontrou uma tradiçào nômade e agrária, desprovida de traços culturais marcantes aos olhos europeus, mas que mostraria uma plasticidade maior de convivência, introduzindo aspectos "nào-formais" de cultura - a culinária, os mitos, a sexualidade - que forçaram a incorporaçào dos modos de vida do indígena. Aos povos-novos caberá, entào, a criaçào de uma cultura original e miscigenada genéticamente na figura do mameluco, trabalhador livre que viabiliza a vida social pelo exercício de atividades que nào podiam ser entregues ao escravo, e, lingüisticamente, impregnando de nomes indígenas a documentaçào histórica dos lugares. 
A partir desta tipologia, Ribeiro classifica as culturas como: mais ou menos integradas conforme a grande confluência interna de seus componentes; culturas autênticas porque seus conteúdos correspondem dos interesses de desenvolvimento autônomo das sociedades que as detêm; espúrias quando integram e justificam o domínio exógeno ou de deformaçào de sua imagem; e de marginalidade cultural quando os modos de participação na cultura sào diferenciados e contrapostos aos do grupo dominante, tornando-se objeto de discriminação. Os contingentes indígenas e africanos eram portadores de culturas autênticas e integradas, mas ao serem submetidos à opressào social e à escravidào, foram "desculturadas" processo que antecedeu o de "aculturaçào" a novas formas de vida que foram compelidas a adotar.

A etnia resultante deste amálgama, depois etnia nacional, surge como cultura espúria e nào integrada.

A tipologia de Darcy encontra ressonância em esforços semelhantes de classificaçào das variaçòes culturais, partindo do pressuposto que existe uma força que, vinda de fora - dos centros difusores europeus ou norte-americanos - nivela as diferenças, e outra, que considera as resistências internas e as condiçòes de integraçào e desenvolvimento entre as regiòes latino-americanas, as difere e subdivide.

Assim, foi mesmo Rama quem citou Darcy (Rama, 1975, p. 78), reservando espaço para outras tipologias "dos conflitos culturais". Ocorreria uma disputa entre estas duas forças, e suas variantes: entre a unidade continental simplificadora da açào ocidental, e as aproximaçòes, lutas, e diferenças entre culturas rurais regionais e urbanas continentais.

Os conflitos têm por base desde o "trauma da conquista", efeito das pressòes hegemônicas, até o drama do "colonialismo interno", açào de reelaboraçào daquelas pressòes entre membros de sociedades nacionais em diferentes estágios de participaçào no progresso industrial de padrào ocidental.

Este cenário aparentemente sem saída é flexibilizado pela açào de intelectuais que tomam partido de sua mestiçagem, destacando elementos de cultura que vào aquecer sua "cosmovisào", nào mais apenas associada à norma "primitivismo", mas também capaz de amalgamar o componente urbano e modernizador às estruturas expressivas tradicionais, o que dá seqüência ao processo de formaçào cultural latino-americano. 


\begin{tabular}{|c|c|c|c|}
\hline \multicolumn{4}{|c|}{ QUADRO COMPARATIVO } \\
\hline FATORES & RA MA & CANCLINI & RIBEIRO \\
\hline Objeto de Estudo & $\begin{array}{l}\text { N arrativa } \\
\text { Literária }\end{array}$ & Bens Culturais & $\begin{array}{l}\text { Processo } \\
\text { Civilizatório } \\
\text { Brasileiro (na } \\
\text { perspectiva } \\
\text { indigen a) }\end{array}$ \\
\hline $\begin{array}{l}\text { Conceito } \\
\text { Operativo }\end{array}$ & Transcultu ração & H ibridação & $\begin{array}{l}\text { Tipologia dos } \\
\text { povos latino- } \\
\text { americanos }\end{array}$ \\
\hline $\begin{array}{l}\text { Definição (do } \\
\text { conceito } \\
\text { operativo } \\
\text { referido) }\end{array}$ & $\begin{array}{l}\text { Mutação do } \\
\text { regionalismo: } \\
\text { coloquialismo e } \\
\text { experimentação }\end{array}$ & $\begin{array}{l}\text { Interação simbólica } \\
\text { ematerial entre } \\
\text { povos de fronteira }\end{array}$ & $\begin{array}{l}\text { Povos } \\
\text { transplantados, } \\
\text { Povos novos, } \\
\text { Povos testemunhos }\end{array}$ \\
\hline $\begin{array}{l}\text { Implicaçöes (na } \\
\text { literatura ena } \\
\text { cultura) }\end{array}$ & $\begin{array}{l}\text { Trânsito entre } \\
\text { linguagem orale } \\
\text { escrita pöe em } \\
\text { suspenso a } \\
\text { linearidade } \\
\text { discursiva e } \\
\text { atualiza a cultura } \\
\text { literária } \\
\text { continental }\end{array}$ & $\begin{array}{l}\text { L egitimação do } \\
\text { consumo; } \\
\text { desreferen ciação } \\
\text { geográfica, } \\
\text { produção } \\
\text { mediatizada, } \\
\text { apropriaçäo dos } \\
\text { discursos alh eios; } \\
\text { pós-modernidade }\end{array}$ & $\begin{array}{l}\text { Retro influência do } \\
\text { nativo sobre o } \\
\text { estrangeiro } \\
\text { americano } x \\
\text { europeu arcaico } x \\
\text { moderno }\end{array}$ \\
\hline $\begin{array}{l}\text { Conceito de } \\
\text { Cultura }\end{array}$ & $\begin{array}{l}\text { Transmissäo de } \\
\text { valores } \\
\text { civilizatórios; } \\
\text { relação dialetais } \\
\text { entreonovo, a } \\
\text { dominaçäo, e a } \\
\text { tradição }\end{array}$ & $\begin{array}{l}\text { Lugar de disputana } \\
\text { definição de } \\
\text { modelos sociais e } \\
\text { econômicos }\end{array}$ & $\begin{array}{l}\text { Estilos de vida; } \\
\text { formas de } \\
\text { adaptação ao meio, } \\
\text { estratégia de } \\
\text { sobrevivên cia; } \\
\text { manutenção, e } \\
\text { desenvolvimento } \\
\text { humanos }\end{array}$ \\
\hline Perfil Intelectual & $\begin{array}{l}\text { Crítico literário e } \\
\text { Professor }\end{array}$ & $\begin{array}{l}\text { Pesquisador } \\
\text { Universitário }\end{array}$ & $\begin{array}{l}\text { Político e Escritor } \\
\text { de ficção }\end{array}$ \\
\hline Obras & $\begin{array}{l}\text { Transcultu raçäo } \\
\text { da narrativa } \\
\text { latino americana } \\
\text { (1975) Cidade das } \\
\text { Letras (1984) }\end{array}$ & $\begin{array}{l}\text { Consumidorese } \\
\text { cidadãos - conflitos } \\
\text { culturaisna } \\
\text { globalização (1995) } \\
\text { Culturas híbridas } \\
\text { (1997) }\end{array}$ & $\begin{array}{l}\text { Processo } \\
\text { civilizatório (1997) } \\
\text { As Am éricas e a } \\
\text { Civilizaçäo (1970) - } \\
\text { Os Brasileiros } \\
(1995) \text { - }\end{array}$ \\
\hline Corpus & $\begin{array}{l}\text { Literatura } \\
\text { indigenista }\end{array}$ & $\begin{array}{l}\text { Situações limites - } \\
\text { fronteiriças - } \\
\text { complexidade } \\
\text { social }\end{array}$ & $\begin{array}{l}\text { Ausência de } \\
\text { tradição - Povos } \\
\text { agrários }\end{array}$ \\
\hline Figuras & $\begin{array}{l}\text { Guimarães Rosa } \\
\text { (dialetos) }\end{array}$ & $\begin{array}{l}\text { Grafiteiros } \\
\text { (rasuras) }\end{array}$ & $\begin{array}{l}\text { M am eluco } \\
\text { (flutuaçäo de } \\
\text { identidade) }\end{array}$ \\
\hline Temporalidade & Moderno & Pós-moderno & Primitivo \\
\hline Espacialidade & Vila & Cidade & Floresta \\
\hline
\end{tabular}




\section{Reterências bibliográticas}

CANCLINI, Néstor Garcia. Culturas híbridas - estratégias para entrar e sair da modernidade. S.Paulo: EdUSP, 1997.

Consumidores e Cidadãos: conflitos multiculturais da globalização. Rio de Janeiro: Edf.UFRJ, 1995.

LIMA, Luís Costa. Da existência precária: o sistema intelectual no Brasil. in "Dispersa Demanda", Rio de Janeiro: Francisco Alves, 1981.

MARCOS, Luís Humberto. O poder dos media e a imagem da América latina em Portugal. in INTERCOM, Revista Brasileira de Comunicação. São Paulo, Vol. XVII, nº 2, p. 66-74, jul-dez 1994.

MENDES JR., João. Os indígenas do Brasil, seus direitos individuais e políticos. Tipografia HENNIES irmãos. S.Paulo, 1912.

MENEZES, Ulpiano Bezerra de. A construção original do território americano. in Revista USP, S. Paulo, 1992, p. 8-16.

MOREIRA, Eliezer. América latina: da utopia à integração. in Revista CCBB, junho de 1998, p. 7 a 11.

OITICICA, Hélio. Aspiro ao grande labirinto. Rio de Janeiro: Rocco, 1986.

ORTIZ, Renato. O espaço no mundo contemporâneo. in Revista CCBB, abril de 1996, p. 18-19.

RAMA, Angel. A cidade das letras. São Paulo: Brasiliense, 1984.

Transculturação na narrativa latino-americana. Caderno de Opinião, n² ${ }^{\circ}$, Rio de Janeiro, 1975.

RIBEIRO, Darcy. Réquiem tropical. in "Arte Amazonas". Instituto GoetheBrasília, 1992.

O processo civilizatório. $11^{\mathrm{a}} \mathrm{ed}$. São Paulo: Cia das Letras, 1997.

O povo brasileiro: a formação e o sentido do Brasil. São Paulo: Cia. das Letras, 1995.

As Américas e a civilização. Rio de Janeiro: Civilização Brasileira, 1970,

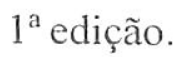

